Discussion Paper No. 08-052

Innovation on Demand -

Can Public Procurement Drive

Market Success of Innovations

Birgit Aschhoff and Wolfgang Sofka

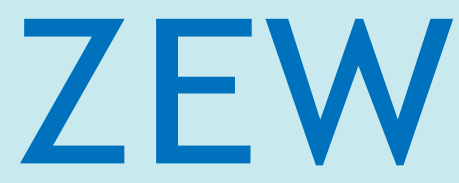

Zentrum für Europäische Wirtschaftsforschung $\mathrm{GmbH}$

Centre for European

Economic Research 
Discussion Paper No. 08-052

\title{
Innovation on Demand - Can Public Procurement Drive Market Success of Innovations
}

\author{
Birgit Aschhoff and Wolfgang Sofka
}

Download this ZEW Discussion Paper from our ftp server:

ftp://ftp.zew.de/pub/zew-docs/dp/dp08052.pdf

Die Discussion Papers dienen einer möglichst schnellen Verbreitung von neueren Forschungsarbeiten des ZEW. Die Beiträge liegen in alleiniger Verantwortung der Autoren und stellen nicht notwendigerweise die Meinung des ZEW dar.

Discussion Papers are intended to make results of ZEW research promptly available to other economists in order to encourage discussion and suggestions for revisions. The authors are solely responsible for the contents which do not necessarily represent the opinion of the ZEW. 


\section{Non-technical Summary}

As innovation is acknowledged to be a key driver of economic growth, governments promote innovation activities both in the public and in the private sector. There are different instruments available to stimulate innovation activities of the private sector. Public procurement has been at the centre of recent discussions on innovation policy on both European and national levels (e.g., Aho-Report, Barcelona Strategy). This might have a large potential to stimulate innovation since it accounts for $16 \%$ of combined EU-15 GDP. In Germany, public procurement spending is around 260 billion Euros a year and thus takes up about $12 \%$ of GDP.

In this study, we conceptually explore the specific features of public procurement as an instrument of innovation policy and embed public procurement into the broader context of stimulating innovation in enterprises by public policy. More precisely, we identify shared and distinctive features of public procurement compared to other major policy instruments, i.e. copublic funding for private innovation projects, knowledge spillovers from publicly funded universities as well as intervention through regulation.

Empirically, we translate this analytical framework into a comparative assessment of how public procurement performs relative to these other policy options. We measure performance in terms of the market success of firms' innovations. Moreover, we question whether these effects apply uniformly to all firms, independent of their size or the industry and region they are operating in. Instead, we suggest that firms are heterogeneous with regard to whether certain policy instruments are relevant, accessible or useful to them. As a result, distinct subpopulations of firms can be identified that respond differently to various combinations of policy instruments. Our empirical investigation rests upon a survey of more than 1,100 innovative firms in Germany. Our survey puts us in the position to trace all sources of valuable innovation impulses, namely public customers, law and regulations, universities and public funding for R\&D. We relate these sources back to innovation success.

We find that public policy leverage points are limited neither to the supply nor the demand side. Public procurement has significant positive effects on innovation success but so does the provision of a knowledge infrastructure in universities spilling over to firms. Both effects have similar impacts on innovation success. Interestingly, the positive effects of public procurement stem from general administrative procurement and not from defense related public procurement. In a second step, we explore whether these effects vary across firms. The benefits of university knowledge apply uniformly to all firms. However, public procurement is especially effective for smaller firms in regions under economic stress as well as in distributive and technological services. Based on these findings targeted policy recommendations are developed. 


\section{Das Wichtigste in Kürze (Summary in German)}

Innovative Produkte und Dienstleistungen sind weitgehend als Grundlage des wirtschaftlichen Wachstums akzeptiert. Staatliche Stellen unterstützen deshalb Innovationsaktivitäten im privaten Sektor mit einer Reihe von Maßnahmen. Besonderes Augenmerk hat dabei in jüngster Vergangenheit die Rolle staatlicher Beschaffungsmaßnahmen mit Blick auf deren Innovationseffekte erhalten. Diese Diskussion wird gegenwärtig sowohl auf nationaler wie auf Europäischer Ebene geführt (z.B. AhoBericht, Barcelona-Strategie). Die potenziellen Auswirkungen von gezielt eingesetzten staatlichen Beschaffungsmaßnahmen sind angesichts der Größenordnung des Beschaffungsbudgets erheblich (260 Mrd. € oder 12\% des BIP jährlich in Deutschland und sogar $16 \%$ des BIP von EU-15).

Im Zentrum der vorliegenden Analyse steht die konzeptionelle Integration des Innovationsinstruments öffentliche Beschaffung in den breiteren Kontext der Forschungsförderung. Dabei werden insbesondere Gemeinsamkeiten und Unterschiede zwischen öffentlichen Beschaffungsmaßnahmen und anderen dominanten Formen der Forschungsförderung mit Blick auf ihre Innovationswirkung untersucht. Diese Vergleichsinstrumente setzen sich zusammen aus finanzieller Förderung privater Innovationsprojekte durch den Staat, Wissenstransfers von Universitäten und regulatorischen Eingriffen.

An diese konzeptionelle Diskussion schließt sich der empirische Test mittels einer komparativen Studie zur Wirkung der einzelnen Politikoptionen auf den Innovationserfolg an. Gemessen ist der Innovationserfolg dabei als der erzielte Umsatz mit neuen Produkten. Die empirische Studie untersucht basierend auf Umfrageinformationen von mehr als 1,100 Unternehmen in Deutschland die Effekte aller vier Politikoptionen (öffentliche Beschaffung, finanzielle Förderung, Wissenstransfer aus Universitäten und Regulierung). Die Studie hinterfragt dabei zusätzlich, ob diese Effekte für alle Unternehmen im selben Maße auftreten oder auf Unternehmen mit einer bestimmten Größe oder aus bestimmten Branchen und Regionen begrenzt bleiben.

Im Ergebnis zeigt sich, dass sowohl öffentliche Beschaffungsmaßnahmen als auch der Wissenstransfer aus Universitäten signifikant positiv zum Innovationserfolg beitragen. Interessanterweise stammt der Effekt öffentlicher Beschaffung aus dem generellen Beschaffungsbedarf (z.B. Verwaltung) und nicht aus dem Bereich Verteidigung und öffentliche Sicherheit. Die differenziertere Analyse legt dabei offen, dass Wissenstransfers aus Universitäten für alle Unternehmen gleichermaßen positiv auf den Innovationserfolg wirken. Der Effekt von öffentlichen Beschaffungsmaßnahmen ist demgegenüber insbesondere spürbar bei kleinen Unternehmen aus dem distributiven und technologischen Dienstleistungsbereich in ökonomisch belasteten Regionen. Auf dieser Basis können gezielt Politikempfehlungen abgeleitet werden. 


\title{
Innovation on Demand - Can Public Procurement Drive Market Success of Innovations?
}

\author{
Birgit Aschhoff* and Wolfgang Sofka \\ Centre for European Economic Research (ZEW), Mannheim, Germany
}

July 2008

\begin{abstract}
Public procurement has been at the centre of recent discussions on innovation policy on both European and national levels (e.g., Aho-Report, Barcelona Strategy). It has a large potential to stimulate innovation since it accounts for $16 \%$ of combined EU-15 GDP. We embed public procurement for innovation into the broader framework of public policies to stimulate innovation: regulations, $R \& D$ subsidies and knowledge infrastructure (i.e. basic research at universities). We synthesize the characteristics of all four instruments based on existing literature and quantitatively compare their effects on innovation success. Our empirical investigation rests upon a survey of more than 1,100 innovative firms in Germany. Our survey puts us in the position to trace all sources of valuable innovation impulses, namely public customers, law and regulations, universities and public funding for R\&D. We relate these sources back to innovation success. We find that (non-defense related) public procurement and knowledge spillovers from universities propel innovation success equally. In a second step, we explore whether these effects vary across firms (e.g. size, location, industry). The benefits of university knowledge apply uniformly to all firms. However, public procurement is especially effective for smaller firms in regions under economic stress as well as in distributive and technological services. Based on these findings targeted policy recommendations can be developed.
\end{abstract}

Keywords: Innovation policy, public procurement, comparison of instruments, innovation success

JEL-Classification: O38, H32, C34

We thank Marco Ceccagnoli, Georg Licht, Christian Rammer, Stephen Roper, and Phil Shapira for valuable comments. Financial support by the Anglo-German Foundation (AGF) is gratefully acknowledged.

* Corresponding author: Centre for European Economic Research (ZEW), Department of Industrial Economics and International Management, P.O. Box 1034 43, 68034 Mannheim, Germany, Tel.+49/621/1235-182, Fax.+49/621/1235-170, Email: aschhoff@zew.de 


\section{$1 \quad$ Introduction}

As innovation is acknowledged to be a key driver of economic growth, governments promote innovation activities both in the public and in the private sector. The promotion of R\&D is also an essential element of the Lisbon strategy launched in 2000 and further defined by the Barcelona Research Council in 2002. The objective is to increase investment in R\&D to $3 \%$ of GDP by 2010 - two-thirds of this increase should be funded by the private sector so that Europe becomes the most competitive and dynamic knowledge-based economy in the world. There are different instruments available to stimulate innovation activities of the private sector. Public procurement has been revitalized as an innovation policy instrument on both European and national levels. In recent years major initiatives have been launched to foster innovation through public procurement e.g., the Aho-Report (European Commission, 2006); Barcelona Strategy (European Commission, 2003). Public procurement might have a large potential since it accounts for 16\% of combined EU-15 GDP (Georghiou et al., 2003). In Germany, public procurement spending is around 260 billion Euros a year and thus takes up about $12 \%$ of GDP (BMBF, 2006).

Public procurement is only one of many innovation policy instruments. Regulations, R\&D subsidies and the scientific and technological infrastructure have also been identified as other main types of public innovation policy which are designed to improve industrial innovativeness (Rothwell and Zegveld, 1981; Geroski, 1990). In this study, we explore the specific features of public procurement in innovation policy conceptually and embed public procurement into the broader context of stimulating innovation in enterprises by public policy. More precisely, we identify shared and distinctive features of public procurement compared to other major policy instruments, i.e. co-public funding for private innovation projects, knowledge spillovers from publicly funded universities as well as intervention through regulation. Empirically, we translate this analytical framework into a comparative assessment of how public procurement performs relative to these other policy options. We measure performance in terms of the market success of firms' innovations. Moreover, we question whether these effects apply uniformly to all firms, independent of their size or the industry and region they are operating in. Instead, we suggest that firms are heterogeneous with regards to whether certain policy instruments are relevant, accessible or useful to them. As a result, distinct subpopulations of firms can be identified that respond differently to various combinations of policy instruments. Based on these findings, tailor-made policy mixes can be developed to optimize effectiveness. In essence, we ask: Is public procurement an effective instrument to provide public support for innovation compared to other options and if so, for which firms does it work? We explore these research questions empirically for a broad sample of more than 1,100 firms and their innovation activities.

The remainder of the paper is organized as follows. Section 2 reviews the literature on public procurement in innovation policy. Section 3 relates it to other important policy instruments and presents previous empirical results. The database and the estimation strategy for the empirical study are described in section 4 . Section 5 presents its results. Finally, we draw conclusions in section 6 . 


\section{The role of public procurement in innovation policy}

Public procurement has received much attention in recent discussions on favorable innovation policy options, both at the European level, such as in the Barcelona Strategy (European Commission, 2003) and the Aho-Report (European Commission, 2006), and at the national level. In Germany, for example, public demand for innovative products will be extended as part of the federal government's Hightech-Strategy. Examples are intelligent energy concepts for city halls or schools and the equipment of public service cars with novel types of engine/propulsion technologies (BMBF, 2007).

With regards to innovation, public procurement can be divided into two types: the purchase of standard products like paper or paperclips, i.e. involving no innovation, and public technology procurement, i.e. the purchase of new technologies and innovative products and services. The latter category is referred to if a government announces its intention to foster public procurement as an innovation policy instrument. ${ }^{1}$ Public technology procurement is a demand-side instrument and can be defined as the purchase "of a not-yet-existing product or system whose design and production will require further, if not completely novel, technological development work" (Edquist and Hommen, 2000: 5). Ideally, the functional requirements of the demanded product are predefined by the government, but the realization and design are not (see Rothwell and Zegveld, 1981; Geroski, 1990; Edler and Georghiou, 2007). Then, public procurement might be a suitable tool for stimulating the generation and diffusion of technological innovation (Geroski, 1990). The two principal reasons for the use of this policy tool are to satisfy and improve the supply of public services and to meet certain political goals by stimulating demand, e.g. in areas of sustainability or energy efficiency (Dalpé, 1994; TAB, 2006). After the government has placed a tender for a specific need and firms have applied, the decision is made by the government. Only one firm or a consortium of firms gets the order to generate and deliver the product or service. Thus, it is a competitive and selective system. A major advantage of public procurement in innovation policy is that government specifies a desired output and leaves it to the creativity of private businesses to achieve this result with the most effective and efficient technologies.

Since the purchase of the new product by the government is contracted, the market risk for the developing and delivering firm is reduced, because a certain amount of sales is guaranteed. Often, the government is a large scale and major user of innovation and technologies. Thus, it can act as an early-state or lead user which bears the costs of learning and refining novel products. Besides, the public sector's significant scale enables innovative firms to generate experience/scale cost reductions quickly. This should lead to reduced prices and therefore newly created or extended markets for private demand as well. ${ }^{2}$ Through the use of a particular innovation the government can also send positive signals to the private market and increase awareness, so that public procurement might also spill over to the private

\footnotetext{
1 In the following, the term public procurement implies the purchase of technologies. We will use the terms public procurement and public technology procurement interchangeably.

2 For the concept of lead users in innovation see Von Hippel (1986).
} 
market and propel the diffusion of innovations (Rothwell, 1984; Porter, 1991; Edler and Georghiou, 2007). However, there is a risk that the developed product will only meet idiosyncratic demand so that further sales in the market will be limited. This might especially be the case of military demand, as stated, e.g., by Stoneman (1987), Lichtenberg (1989) or James (2004). In addition, the risk that the R\&D project will fail is not reduced. ${ }^{3}$

The role of public procurement in the development of new products and its success have not yet been well analyzed. Several case studies have been conducted; see for example for the USA Cohen and Noll (1991) and for European cases Edquist et al. (2000) or Edler et al. (2005). Examples of both success and failure are known. However, quantitative analyses of which firms are responsive to the stimulation of innovation via public procurement and benefit from the government as a customer are still rare. One aim of this study is to contribute to this literature by empirically investigating the role that public procurement plays for the innovation success of firms.

\section{A comparative perspective on public procurement in innovation policy}

Other forms of public support for private innovation activities have received significant attention in both academic and policy making discussions. They are typically divided into instruments providing additional inputs for private innovation processes (i.e. supply side) and instruments influencing innovation outputs (i.e. demand side). The former is most importantly associated with the public provision of resources, both tangible (e.g. funding) and intangible (e.g. scientific knowledge) in nature, while the latter influences markets for innovative products or services (e.g. through mandatory standards). Public procurement is a demand side instrument. We will briefly outline major features of other important innovation policy instruments: regulation on the demand side and knowledge spillovers from universities as well as R\&D subsidies on the supply side. We conclude the conceptual discussion by drawing a synthesis of all four policy instruments under consideration with regards to shared and distinctive features and a review of comparative studies.

\section{Regulation}

Regulation is a demand side instrument. It refers to the "implementation of rules by public authorities and governmental bodies to influence the behaviour of private actors in the economy" (European Commission, 2004: 4). Regulations can be classified as economic (e.g. antitrust policy, price control), social (e.g. environmental or safety regulation) or administrative (e.g. product liability) regulations (OECD, 1997). Regulation policy can be considered as an indirect method of affecting innovation since it defines the framework conditions for a firm and no public funds are used (Geroski, 1990). However, it has a direct effect on firms since they have to comply with the regulations, e.g., environmental

3 For a more detailed description of public procurement see, e.g. Geroski (1990) or Edler and Georghiou (2007). 
regulations, quality standards. Compliance probably causes additional costs for the firm and delays the time to market. Regulation is a non-selective system since all companies of an industry are affected. A possible exception is an EU Directive, which is not implemented by all European countries in the same way and at the same time (Blind, 2004).

The Fraunhofer Institute for Systems and Innovation Research (2004) analyzes the effects of regulation on innovation empirically. For this purpose about 250 mostly European companies are surveyed. Considering the introduction of new products and services by firms, they find that regulations can have both positive effects - such as protection from liability claims or increased acceptance of new products by consumers and users - and negative impacts - such as increasing labour and development costs. The most important regulations for the introduction of new products and services relate to health and safety aspects, the quality of products and services and the question of liability. ${ }^{4}$ Jaffe et al. (1995) survey the empirical literature on the hypothetical linkages between environmental regulation and different measures of competitiveness. They find little evidence of either an adverse or a stimulating effect of environmental regulations on innovation and competitiveness. With respect to administrative regulation, in particular liability rules such as product safety, Viscusi and Moore (1993) show empirically that liability at low and moderate levels has a positive impact on product innovation whereas at very high levels the effect turns negative. Overall, regulation as a barrier for innovation activities is only a minor factor. Much more important barriers for innovation activities are high economic risks and high innovation costs (Rammer et al., 2005).

The overall effect - and in particular the effect in comparison to other instruments - of regulations on innovation is not unambiguous. Regulations clearly have the potential to stimulate innovations. The question is to what extent this impact is visible and accounts for market novelties in the manufacturing and service sector. It is also worth asking to what extent mandatory standards eliminate opportunities for competing firms to differentiate themselves in competition.

\section{Universities and public research institutions}

Most of the literature deals with supply-side instruments used by the governments to increase business $R \& D$ activities. Public $R \& D$ subsidies and the provision of research infrastructure via universities and public research institutions are the two most important supply-side instruments.

It has already been stated by Rothwell and Zegveld (1980: 50) that "Governments may influence the course of innovation by their support for background basic research and applied research within the scientific and technological 'infrastructure'." Support for universities and public research institutions does not provide direct financial assistance for the business sector. The government rather promotes the generation and provision of scientific and technological knowledge within universities or scientific institutions. Generally, more fundamental research

4 For an overview of different types of regulations and their possible impact on innovation see, e.g., Fraunhofer Institute for Systems and Innovation Research (2004). 
is conducted, which "expands the capability of the economy to generate new inventions and innovations rapidly and effectively" (Geroski, 1990: 183). University research is regarded as an important contributor to technical progress and industrial innovation, in varying degrees to different industries (Nelson and Rosenberg, 1993; Rothwell and Zegveld, 1980; Mansfield, 1991; Pavitt, 1991). The opportunity to access this new knowledge is generally open to all firms. Firms can use it in order to access specialist technical support, to complement internal $\mathrm{R} \& \mathrm{D}$ - which is especially important since research has become more expensive - or it can provide a window on emerging technologies (Tidd et al., 1997). It is the decision of the firm to use this opportunity or not. However, there is also the risk that idiosyncratic knowledge will be generated, which cannot (yet) be used by business firms. In recent years public programs have been developed, e.g., the framework programs by the European Commission, which emphasize the support of collaboration between scientific institutions and firms (Caloghirou et al., 2001).

University-industry relationships can be widely observed (Caloghirou, 2001; Perkmann and Walsh, 2007). A variety of interactions are used, such as joint research, contract research, personnel mobility and training (Schartinger et al., 2002). Several empirical studies investigate the impact of a firm's collaboration with universities and research institutions; most show that firms profit from this type of collaboration. For example, Belderbos et al. (2004) and Aschhoff and Schmidt (2006) show that R\&D collaboration with universities and research institutions increases a firm's sales attributable to market novelties. Miotti and Sachwald (2003) and Lööf and Broström (2008) both confirm for manufacturing firms that this type of collaboration has a positive impact on a firm's probability of applying for a patent. The latter study also finds an increase in a firm's innovative sales. However, several studies warn that these positive effects are limited to certain, mostly high-technology industries and large firms with high R\&D intensities and related absorptive capacities (see, e.g., Cohen et al., 2002; Fontana et al., 2006).

\section{Public R\&D subsidies}

Public funding of private R\&D activities is used as an innovation policy instrument by the governments of most OECD countries. Typically, the government selects specific R\&D projects for which firms have applied for public support. Governments intend to select projects with a high social return that would not have been carried out in the absence of public support. Thus, not all firms benefit from R\&D subsidies. Most schemes work on a cost sharing basis. In Europe, up to 50\% of a firm's R\&D project costs are typically covered by the funding source. Therefore, the funding directly reduces firms' $R \& D$ costs. However, the supply of public R\&D subsidies for firms bears the inherent risk of crowding out company financed $R \& D$ expenditures, since every company is keen to reduce $R \& D$ costs and thus may apply for financial support. Public subsidies can be classified as a direct instrument since they provide financial support for firms. In contrast to the other policy instruments, R\&D subsidies focus on the development of new technologies, not on the diffusion of the generated technology.

A lot of studies have been conducted in order to investigate the effects of R\&D subsidies, in particular in the context of evaluations. The effects found were mixed (for an overview see, 
e.g., David et al., 2000, or Aerts et al., 2007). However, most of the empirical studies for German firms certify a positive effect of subsidies on innovation input (Fier, 2002; Czarnitzki and Fier, 2002; Almus and Czarnitzki, 2003). A positive effect of subsidies was also found on companies' patent activities (Czarnitzki and Hussinger, 2004; Czarnitzki and Licht, 2006).

Another form of public financial support for private R\&D could be provided in the form of R\&D tax credits. Since our subsequent empirical analysis is limited to Germany, where the instrument of R\&D tax credits is currently not employed, we will not explore it in more detail conceptually.

\section{Synthesis}

Overall, all four instruments have the potential to encourage and stimulate innovations. Table 1 summarizes the previous discussion. The number of empirical studies on effects and effectiveness of supply-side instruments is enormous, in particular regarding R\&D subsidies. Astonishingly, there is only little empirical evidence on the effect of demand-side instruments on innovation and little has been done to compare the effects of different instruments. Hence, our goal is to extend the existing literature by comparing all four instruments with regards to their effect on market success with innovation.

Table 1: Characteristics of the four policy instruments from a firm's perspective

\begin{tabular}{lcccc}
\hline & $\begin{array}{c}\text { Public } \\
\text { procurement }\end{array}$ & Regulation & $\begin{array}{c}\text { Research } \\
\text { institutions \& } \\
\text { universities }\end{array}$ & $\begin{array}{c}\text { Public R\&D } \\
\text { subsidies }\end{array}$ \\
\hline Input & money & none & knowledge & money \\
\hline $\begin{array}{l}\text { Primary } \\
\text { participation } \\
\text { incentive for } \\
\text { firms }\end{array}$ & sales & mandatory & $\begin{array}{c}\text { access to } \\
\text { knowledge }\end{array}$ & cost/risk sharing \\
\hline Selection by & state & none & firm & state \\
\hline $\begin{array}{l}\text { Effect on } \\
\text { success }\end{array}$ & $\begin{array}{c}\text { market risk } \\
\text { reduction }\end{array}$ & $\begin{array}{c}\text { market risk } \\
\text { reduction }\end{array}$ & $\begin{array}{c}\text { technological } \\
\text { opportunity }\end{array}$ & cost reduction \\
\hline $\begin{array}{l}\text { Inherent risk } \\
\text { idiosyncratic } \\
\text { demand }\end{array}$ & $\begin{array}{c}\text { "egalitarianism" } \\
\text { idiosyncratic } \\
\text { knowledge }\end{array}$ & $\begin{array}{c}\text { crowding out of } \\
\text { private R\&D } \\
\text { investments }\end{array}$ \\
\hline
\end{tabular}

Previous research with a similar focus on investigating several instruments simultaneously is rather scarce and has led to mixed results. On the one hand, Rothwell and Zegveld (1981) find that demand is the most important means used by the government to trigger technical innovation; subsidies are the least important instrument. Regulation is not found to prevent innovation to a significant extent. The infrastructure support and universities could also develop some major inventions. Geroski (1990) also assesses public procurement as a greater stimulus for industrial innovativeness than R\&D subsidies. On the other hand, Palmberg (2004) finds that environmental issues and regulations/standards contribute more to the origin of innovations than scientific breakthrough and public research programs. Public procurement is found to be the least important factor for the origin of innovations. 
We suspect that these mixed results can be traced back to structural features in firm characteristics which influence their reactions to different policy instruments. We investigate two major factors:

- Firm resources

Firms require certain resources to participate successfully in different types of policy instruments. Cohen et al. (2002) and Fontana et al. (2006) show, for example, that firm size and age determine a firm's probability of engaging in research collaboration with research institutions. Promising channels for knowledge transfers need to be established over time and require substantial resource commitments (Laursen and Salter, 2006). Younger and smaller firms may be lack these resources.

- Geographic and industry opportunity

A firm's geographic location or industry may mitigate or reinforce its reaction to certain policy instruments. For example, Grimpe and Sofka (2008) show that firms in high-tech industries are more likely to engage in knowledge sourcing from universities. Besides, high quality research institutions may be concentrated in certain regions within a country. At the same time, regulations and R\&D subsidy programs may be targeted at specific industries or regions. For example, the EU structural funds program sets a certain threshold for GDP per capital for European regions to qualify for participation.

\section{$4 \quad$ Empirical study}

\subsection{Data}

For the empirical part of this analysis we use cross-section data from a survey on the innovation activities of German enterprises called the "Mannheim Innovation Panel" (MIP). The survey is conducted annually by the Centre for European Economic Research (ZEW) on behalf of the German Federal Ministry of Education and Research. The methodology and questionnaire used by the survey, which is targeted at enterprises with at least five employees, are the same as those used in the Community Innovation Survey (CIS), conducted every four years under the coordination of Eurostat. For our analysis we use the 2003 survey, in which data was collected on the innovation activities of enterprises during the three-year period 2000-2002. ${ }^{5}$ Non-innovating firms are excluded from our analysis. Our empirical analysis rests upon 1,149 company observations from both manufacturing and service sectors, for which all the variables needed for our model are available.

CIS surveys are self-reported and represent subjective assessments. This raises quality issues with regards to administration, non-response and response accuracy (for a recent discussion see Criscuolo et al., 2005). Several features of our survey helped minimize these

5 The sample was drawn using the stratified random sample technique. For a more detailed description of the dataset and the survey see Rammer et al. (2005). 
potential problems. First, our CIS survey was administered via mail, which means that it does not suffer from certain shortcomings and biases of telephone interviews (for a discussion see Bertrand and Mullainathan, 2001). The multinational application of CIS surveys adds extra layers of quality management and assurance. CIS surveys are subject to extensive pre-testing and piloting in various countries, industries and firms with regards to interpretability, reliability and validity (Laursen and Salter, 2006). Second, a comprehensive non-response analysis of more than 4,000 firms showed no systematic differences between responding and non-responding firms with respect to their innovation activities. Third, the questionnaire contains detailed definitions and examples to increase response accuracy. Longhand questions (e.g. "Please describe your most important product innovation briefly") allow robustness checks for multiple choice answers.

In conclusion, the major advantages of CIS surveys are that they provide direct, importanceweighted measures for a comprehensive set of issues (Criscuolo et al., 2005). This information is self-reported. Heads of R\&D departments or innovation management are asked directly if and how they are able to generate innovations. This immediate information on processes and outputs can complement traditional measures of innovation such as patents (Kaiser, 2002; Laursen and Salter, 2006).

\subsection{Variables}

\section{Dependent variable}

Researchers have discussed several concepts for measuring innovation success (for an overview see OECD, 2005). They range from innovation inputs ( $\& D$ expenditures) to the outputs of innovation activities, e.g. patents, new processes and products. We choose the latter approach. While each new product may be valuable in itself, the success of the firm that produces it depends heavily on its market acceptance. Hence, we conceptualise innovation success as the share of turnover achieved with new products. Besides, new products have varying degrees of novelty, i.e. whether they are just new to the firm, or to the market as a whole. The former may be more related to imitative behaviour whereas the latter is more closely related to radical innovation success. We opt for the share of turnover with market novelties ${ }^{6}$ as our dependent variable, in line with several other studies in the field (see for example Laursen and Salter, 2006).

\section{Focus variables}

Our survey provides us with the unique opportunity to capture all policy instruments described in the theoretical part. We generate the key variable of our investigation, public procurement, based on an open question asking which industry the customers that triggered innovation belonged to. ${ }^{7}$ We consider public procurement as an important source of

6 By definition this is a novelty in a firm's relevant market and not necessarily a "new to the world" innovation.

7 The question is part of a section that initially defines external sources for innovation as impulses that were indispensable for the firm's new products, services or processes. The exact question is: "Have you introduced significantly improved products or processes between 2000 and 2002 because specific customers 
innovation for a firm if the respondents indicate that the customers came from public administration, defense or compulsory social security (NACE 75.1, 75.2 and 75.3) and construct a corresponding dummy variable. As a consistency check we split up this variable into defense (75.2) and non-defense public procurement and estimate a separate model for each. A separate question asks for laws and regulations that were essential impulses for innovation in the firm. We add a dummy variable indicating whether this was the case. We capture innovation impulses from universities in the same way, i.e. through a separate dedicated question and the generation of a corresponding dummy variable. Thereby, universities also include public R\&D laboratories, non-university research institutions etc. Finally, we are able to utilize a separate, direct question on whether the firm received public funding for an innovation project and add another dummy variable.

\section{Control variables}

We add several control variables to our model to control for other factors influencing a firm's success with market novelties. Most importantly, we control for the firm's own R\&D expenditures (as a fraction of sales) and whether R\&D is performed continuously over time (dummy variable). These two variables measure a firm's absorptive capacity which has been found crucial for successful innovation activities (Cohen and Levinthal, 1990). Besides, we control for other structural features: firm size (number of employees), firm age, location in Eastern Germany (dummy), internationalization (exports as a share of sales) and whether the firm is a subsidiary of a foreign firm (dummy). Finally, we add five dummy variables controlling for industry effects: medium-high tech manufacturing, high tech manufacturing, distributive services, knowledge intensive services and technological services. Low tech manufacturing will serve as the comparison group in all estimations. The detailed industry classification can be found in Table 6 in appendix A.

\subsection{Descriptive statistics}

The median firm in our sample has about 80 employees. Because the largest firm has about 200,000 employees, the average is rather high, at 820 employees (Table 2). In order to control for the skewed distribution we use the logarithm of the number of employees in the regressions. The average firm is 17 years old. Since the sample is restricted to firms with innovation activities, the absorptive capacity variables are higher than the German average. Firms spend an average of $6 \%$ of their sales on R\&D and about $80 \%$ of the firms in our sample conduct R\&D on a continuous basis. Regarding firms' internationalization, almost a quarter of the sales were exports and $9 \%$ of the firms have their headquarters abroad. One third of the firms are located in Eastern Germany and 30\% of the firms are active in the manufacturing sector.

Of the four types of intervention, public procurement seems to be the least important for innovation activities. Only $5 \%$ of the firms are involved in public procurement contracts

asked for them or demanded them directly? If yes, from which industry did they come?" In case of academic sources: “... were only made possible through new research results by universities or public research institutions.” In case of regulation: “... were triggered by new laws or regulations.” 
which contribute significantly to the firm's innovation activities, with $1 \%$ relating to defense procurement and $4 \%$ to other procurement. In contrast, domestic universities and research institutions are important sources of information for $13 \%$ of the firms. $18 \%$ implemented innovations which were triggered by regulation and laws. The most prevalent of the four types of intervention is public funding. One third of the firms receive $R \& D$ subsidies.

On average, about $10 \%$ of the sales are generated by market novelties. We also calculate this share of sales for four subsamples, consisting of firms which were affected by a specific intervention. Firms for which public procurement is an important innovation impulse realize $18 \%$ of their sales with new-to-the-market products. Firms with universities as an important information source generate $14 \%$ of their sales with market novelties, followed by firms which receive public funding (11\%). The corresponding share of sales for firms in which regulations triggered innovations equals $10 \%$. In the next step the effects of the four types of intervention on the innovation success are analyzed in a multivariate context.

Table 2: Descriptive statistics (1,149 observations)

\begin{tabular}{|c|c|c|c|c|}
\hline Variable & Mean & $\begin{array}{l}\text { Std. } \\
\text { Dev. }\end{array}$ & Min & Max \\
\hline \multicolumn{5}{|l|}{ Dependent Variables } \\
\hline \multicolumn{5}{|l|}{ For subsample } \\
\hline Innovation source: Public procurement (d) & 17.095 & 26.696 & 0 & 100 \\
\hline Innovation source: Regulation (d) & 10.435 & 19.469 & 0 & 100 \\
\hline Innovation source: Domestic university (d) & 14.272 & 20.884 & 0 & 100 \\
\hline Public funding for innovation (d) & 11.733 & 19.008 & 0 & 100 \\
\hline \multicolumn{5}{|l|}{ Focus Variables } \\
\hline Innovation source: Public procurement (d) & 0.048 & 0.214 & 0 & 1 \\
\hline Innovation source: Public procurement Admin (d) & 0.037 & 0.190 & 0 & 1 \\
\hline Innovation source: Public procurement Defense (d) & 0.011 & 0.106 & 0 & 1 \\
\hline Innovation source: Regulation (d) & 0.178 & 0.382 & 0 & 1 \\
\hline Innovation source: Domestic university (d) & 0.126 & 0.332 & 0 & 1 \\
\hline Public R\&D subsidy (d) & 0.347 & 0.476 & 0 & 1 \\
\hline \multicolumn{5}{|l|}{ Control Variables } \\
\hline Continuous R\&D (d) & 0.810 & 0.392 & 0 & 1 \\
\hline R\&D expenditure as a share of total sales (ratio) & 0.060 & 0.114 & 0 & 0.88 \\
\hline No. of employees (logs) & 4.499 & 1.815 & 0 & 12 \\
\hline Firm age (years) & 17.232 & 15.317 & 0 & 96 \\
\hline Location Eastern Germany (d) & 0.329 & 0.470 & 0 & 1 \\
\hline Exports as a share of total sales (ratio) & 0.238 & 0.266 & 0 & 1 \\
\hline Headquarters abroad (d) & 0.087 & 0.282 & 0 & 1 \\
\hline Other manuf. (d) & 0.320 & 0.467 & 0 & 1 \\
\hline Medium-high technology manuf. (d) & 0.248 & 0.432 & 0 & 1 \\
\hline High technology manuf. (d) & 0.136 & 0.343 & 0 & 1 \\
\hline Distributive services (d) & 0.067 & 0.250 & 0 & 1 \\
\hline Knowledge-intensive services (d) & 0.070 & 0.255 & 0 & 1 \\
\hline Technological services (d) & 0.159 & 0.366 & 0 & 1 \\
\hline
\end{tabular}

Note: d: dummy variable 
No severe collinearity problems between the explanatory variables, which could bias the estimation results, are detected (see Table 7 in appendix A). We can be confident that no collinearity issues exist because the variance inflation factors of the variables are satisfactory (for further description see, e.g., Neter et al., 1990, or Rabe-Hesketh and Everitt, 2007). ${ }^{8}$

\subsection{Estimation strategy}

\section{Econometric approach}

We choose a reduced form model approach to test our theoretical argumentation. The available data structure does not allow us to choose a more extensive structural model which would explicitly address the possibility that firm participation in the four policy instruments may not be a fully random process. Therefore, we cannot completely rule out a potential selection bias. However, we believe that limiting our sample to innovative firms only (firms with innovative outputs) mitigates potential biases.

\section{Tobit regressions}

Our dependent variable is the share of sales with market novelties. While all firms in our sample are successful innovators, it cannot be assumed that all of their innovations were not just new to the firm but new to the market as a whole. In fact, $45 \%$ of the firms do not develop and sell market novelties. In order to take this censoring of the dependent variable into account, our estimation strategy is based on tobit models.

\section{Latent class tobit regression}

It is reasonable to assume that the effects of the four interventions are not the same for all firms, i.e. we expect them to vary with firm size, age, location, and sector. We suggest that subpopulations of firms with distinctive features exist in our dataset and that relationships between policy instruments and innovation outputs (market success) differ significantly between these subpopulations. While the former issue is traditionally addressed through cluster analytical methods, the latter would typically require regression analysis. We rely on latent class tobit estimation analysis, which allows us to cover both aspects simultaneously. This technique was introduced by Lazarsfeld (1950) for identifying patterns in survey responses. Latent classes are unobservable (latent) subgroups or segments. The goal of latent class analysis is to identify subgroups of observations that are similar to other subgroup members, in terms of predefined variables, but dissimilar to members of other subgroups. In this sense, latent class analysis differs from other continuous latent variable approaches (like random-effects regression), as the identification of groups (or categories) is the primary goal. It therefore follows a finite mixture model rationale, i.e. a dataset is disentangled into a finite mixture of distinctly different populations. It is superior to traditional cluster analysis as it is based on a statistical model which allows for significance tests and measurements of fit (Jensen et al., 2007; for a detailed discussion see Hagenaars and McCutcheon, 2002).

8 There are different rules-of-thumb regarding the cut-off points when multi-collinearity is a problem. The values range between 4 and 10. The highest factor in our study equals 1.27 . In addition, the correlation matrix of the explaining variables is shown in Table 8 in appendix A. 
Latent class analysis can be combined with regression analysis by specifying a set of variables (covariates) that influence the conditional probability of a certain observation belonging to a certain class, as well as variables that influence the dependent variable (predictors). Put simply, the problem of assigning observations to latent classes and obtaining separate regression results for each class is solved in one optimization step. Latent class regression analysis can therefore be considered more general than traditional regression analysis that assumes that all observations are homogeneous.

The general probability structure is:

$$
f\left(y_{i} \mid x_{i}^{\mathrm{cov}}, x_{i}^{\text {pred }}\right)=\sum_{x=1}^{K} P\left(z \mid x_{i}^{\mathrm{cov}}\right) f\left(y_{i} \mid z, x_{i}^{\text {pred }}\right)
$$

where the probability of outcome $y$ (share of sales with market novelties) for observation $i$ depends upon the conditional probability of belonging to one of $K$ latent classes (with $z$ as the latent variable) based on a vector $x$ of covariate variables $\left(x^{c o v}\right)$ and a vector $x$ of predictors $\left(x^{\text {pred }}\right)$. We assume that a firm's exposure to various policy instruments can be condensed into a finite number of patterns (latent classes) depending upon size, firm age, location (Eastern Germany) and industry (covariates). Besides, we can test at the same time whether differences exist between the effects of the various policy instruments (predictors) on market success given that firms belong to a certain pattern (i.e. are part of a particular latent class). Again we formulate the regression as a tobit model and carry it out using the algorithm provided by Vermunt and Magidson (2005).

\section{$5 \quad$ Results}

Table 3 presents the results of our tobit estimations. We estimate two separate models. Model 1 contains all forms of public procurement in a single variable while Model 2 separates defense related public procurement (including police and fire department needs) from the rest (e.g. public administration, social security agencies). Most importantly, we find that public procurement has a positive and significant effect on innovation success (measured as sales with new-to-the-market products). A comparison between Models 1 and 2 reveals that this positive effect does not stem from defense/security related public procurement but from more conventional branches of public procurement, such as purchases for general administrative needs. In this sense, we support existing literature on the topic which questions the potential of defense procurement to stimulate innovation (Geroski, 1990). 
Table 3: Tobit models for the share of turnover with market novelties

\begin{tabular}{|c|c|c|}
\hline & Model 1 & Model 2 \\
\hline \multicolumn{3}{|l|}{ Focus Variables } \\
\hline Innovation Source: Public procurement (d) & $\begin{array}{c}9.44 * * \\
(4.17)\end{array}$ & \\
\hline Innovation Source: Public procurement Admin (d) & & $\begin{array}{l}7.93 * \\
(4.72)\end{array}$ \\
\hline Innovation Source: Public procurement Defense (d) & & $\begin{array}{l}11.09 \\
(8.22)\end{array}$ \\
\hline Innovation Source: Regulation (d) & $\begin{array}{l}-0.89 \\
(2.43)\end{array}$ & $\begin{array}{l}-0.90 \\
(2.43)\end{array}$ \\
\hline Innovation Source: Domestic university (d) & $\begin{array}{l}5.27 * \\
(2.77)\end{array}$ & $\begin{array}{l}5.32 * \\
(2.77)\end{array}$ \\
\hline Public R\&D subsidy (d) & $\begin{array}{c}1.04 \\
(2.08)\end{array}$ & $\begin{array}{c}1.04 \\
(2.08)\end{array}$ \\
\hline \multicolumn{3}{|l|}{ Control Variables } \\
\hline Continuous R\&D (d) & $\begin{array}{l}4.86^{*} \\
(2.53)\end{array}$ & $\begin{array}{l}4.94 * \\
(2.53)\end{array}$ \\
\hline R\&D expenditure as a share of total sales (ratio) & $\begin{array}{c}33.16^{* * * *} \\
(8.71)\end{array}$ & $\begin{array}{c}32.82 * * * \\
(8.74)\end{array}$ \\
\hline No. of employees (logs) & $\begin{array}{l}-0.18 \\
(0.58)\end{array}$ & $\begin{array}{c}-0.19 \\
(0.58)\end{array}$ \\
\hline Firm age (years) & $\begin{array}{c}-0.25 * * * \\
(0.07)\end{array}$ & $\begin{array}{c}-0.25^{* * *} * \\
(0.07)\end{array}$ \\
\hline Location Eastern Germany (d) & $\begin{array}{c}-5.28 * * \\
(2.10)\end{array}$ & $\begin{array}{c}-5.28 * * \\
(2.10)\end{array}$ \\
\hline Exports as a share of total sales (ratio) & $\begin{array}{c}2.59 \\
(3.91)\end{array}$ & $\begin{array}{c}2.51 \\
(3.91)\end{array}$ \\
\hline Headquarters abroad (d) & $\begin{array}{c}1.13 \\
(3.20)\end{array}$ & $\begin{array}{c}1.04 \\
(3.22)\end{array}$ \\
\hline Medium-high technology manuf. (d) & $\begin{array}{l}4.26^{*} \\
(2.46)\end{array}$ & $\begin{array}{l}4.33 * \\
(2.46)\end{array}$ \\
\hline High technology manuf. (d) & $\begin{array}{l}6.64 * * \\
(2.93)\end{array}$ & $\begin{array}{c}6.61 * * \\
(2.94)\end{array}$ \\
\hline Distributive services $(d)$ & $\begin{array}{l}-2.35 \\
(4.07)\end{array}$ & $\begin{array}{l}-2.23 \\
(4.07)\end{array}$ \\
\hline Knowledge-intensive services (d) & $\begin{array}{c}2.41 \\
(3.87)\end{array}$ & $\begin{array}{c}2.52 \\
(3.87)\end{array}$ \\
\hline Technological services (d) & $\begin{array}{c}0.42 \\
(3.09)\end{array}$ & $\begin{array}{c}0.51 \\
(3.08)\end{array}$ \\
\hline Constant & $\begin{array}{l}-4.09 \\
(3.77)\end{array}$ & $\begin{array}{l}-4.08 \\
(3.78)\end{array}$ \\
\hline Wald $\chi^{2}$ & 82.23 & 81.77 \\
\hline P-value & 0.00 & 0.00 \\
\hline Aldrich-Nelson Pseudo $\mathrm{R}^{2}$ & 0.08 & 0.08 \\
\hline No. of obs. & 1,149 & 1,149 \\
\hline
\end{tabular}

Notes: $\quad * * *(* *, *)$ indicate a significance level of $1 \%(5 \%, 10 \%)$. Wald $\chi^{2}$ displays the Wald test statistic for the joint significance of the explanatory variables. The next line reports the corresponding p-value. Coefficients are shown (standard errors in parenthesis). 
A major goal of this study is to compare the innovation effects of public procurement with other forms of public support. Our results suggest that only knowledge spillovers from universities have equally strong positive effects on market success with innovation products as public procurement. At first glance the impact of public procurement appears to be much stronger, but additional t-tests show that this difference between the two coefficients is not statistically significant. Neither regulation nor public funding for innovation projects seems to have a significant impact on market success. In the case of regulation this may be related to the way in which we capture innovation success. We are focusing on the sales of products which are not just new to the firm but also new to the whole market. A mandatory, market wide regulatory standard may set the bar for all firms equally and limit opportunities for differentiation. Public co-funding of innovation projects, though, may be more closely related to building basic innovation assets for the future instead of fostering immediate market success.

Coefficients of control variables remain stable in both models. We develop no a priori hypotheses on their relationships with market success but major findings will be discussed briefly. Not surprisingly, investments in R\&D activities (as a share of sales) as well as engaging in them continuously (often associated with having a dedicated R\&D department) are positively and significantly associated with innovation success. Firm age seems to be more closely related to innovation success than firm size, as younger firms are more likely to generate larger portions of their sales with market novelties. Besides, firms in the economically challenged Eastern part of Germany have significantly smaller shares of sales with market novelties. Finally, firms from medium-high (e.g. automotives) as well as high tech manufacturing sectors (e.g. medical instruments) have significantly higher shares.

The previous estimations modeled additive relationships between various forms of public support for innovation (e.g. public procurement) and several structural features (e.g. firm size, age, industry). We estimate additional latent class tobit models to investigate whether the effects of these forms of public intervention differ, given certain structural features. Latent class tobit estimation allows us to model homogeneous subgroups of firms based on their size, age, location (East/West Germany) and industry. At the same time, it enables us to model the relationship between different forms of public support and innovation success within these subgroups.

Identifying the correct number of clusters or classes is challenging with traditional cluster analysis techniques (e.g. K-Means). Each additional cluster provides a better fitting solution (in its extreme form, each observation would be in its own class) but too many classes make it hard to identify and interpret meaningful structures. Hence, a parsimonious solution is required. Latent class cluster analysis rests upon a formal statistical model and therefore provides quantitative indicators for choosing a fitting number of clusters. This decision is typically based upon two key figures: the Bayesian information criteria (BIC) and the Akaike information criteria (AIC). Both compare the exploratory power of a model with one additional cluster to the number of parameters required to estimate it. Hence, these criteria should be minimized to indicate an appropriate number of classes. Andrews and Currim 
(2003) compare a number of criteria and find $\mathrm{AIC}^{9}$ to be the most appropriate. We follow their advice and retain a two class solution. Each class covers roughly half of all firm observations. Table 4 provides statistical details as well as probabilities for class membership. We will present class assignments and performance relationships (see Table 5) separately for clarity and convenience in interpretation. However, it should be kept in mind that both estimations are performed simultaneously.

\section{Table 4: Class profiles}

\begin{tabular}{lcccc}
\hline Covariates & Base Class & Focus Class & Wald & p-value \\
\hline No. of employees (logs) & 0.12 & -0.12 & 10.23 & 0.00 \\
Firm age (years) & 0.00 & 0.00 & 1.06 & 0.30 \\
Location Eastern Germany (d) & -0.33 & 0.33 & 6.51 & 0.01 \\
Medium-high technology manuf. (d) & 0.16 & -0.16 & 1.09 & 0.30 \\
High technology manuf. (d) & -0.02 & 0.02 & 0.01 & 0.93 \\
Distributive services (d) & -0.60 & 0.60 & 3.06 & 0.08 \\
Knowledge-intensive services (d) & -0.04 & 0.04 & 0.02 & 0.88 \\
Technological services (d) & -0.37 & 0.37 & 3.85 & 0.17 \\
Constant & -0.29 & 0.29 & & \\
\hline Class size (in \%) & 51 & 49 & & \\
\hline Model Selection & & & \\
BIC(LL) 1-Cluster: 6,639.34; 2-Cluster: 6,422.36; 3-Cluster: 6,508.85; 4-Cluster: 6,600.95 & \\
AIC3(LL) 1-Cluster: 6,598.87; 2-Cluster: 6,305.01; 3-Cluster: 6,314.61; 4-Cluster: 6,329.82 & \\
\hline
\end{tabular}

Table 4 provides probabilities of class membership. We conduct Wald tests on significant effects (last column of Table 4). Hence, firm size, location in Eastern Germany and operating in distributive as well as technological services influence class assignments significantly. We find that smaller firms in Eastern Germany from distributive (e.g. transportation) as well as technological services (e.g. software development) characterize class 2, which we will subsequently refer to as the "focus class." Firms without these characteristics are more likely to end up in the slightly larger "base class" 1 . Table 5 shows the results of the simultaneous performance tobit estimations in each class.

Table 5: Latent class tobit models for the share of turnover with market novelties

\begin{tabular}{|c|c|c|c|c|c|c|}
\hline & \multicolumn{2}{|c|}{ Coefficient } & \multirow[t]{2}{*}{ Wald } & \multirow[t]{2}{*}{ p-value } & \multirow[t]{2}{*}{ Wald (=) } & \multirow[t]{2}{*}{ p-value } \\
\hline & $\begin{array}{l}\text { Base } \\
\text { Class }\end{array}$ & $\begin{array}{l}\text { Focus } \\
\text { Class }\end{array}$ & & & & \\
\hline Innovation Source: Public procurement (d) & -3.330 & 29.100 & 7.070 & 0.03 & 7.000 & 0.01 \\
\hline Innovation Source: Regulation (d) & -0.401 & -3.003 & 0.383 & 0.83 & 0.108 & 0.74 \\
\hline Innovation Source: Domestic university (d) & 3.641 & 7.604 & 8.726 & 0.01 & 0.216 & 0.64 \\
\hline Public R\&D subsidy (d) & 1.081 & -0.003 & 0.979 & 0.61 & 0.026 & 0.87 \\
\hline Continuous R\&D (d) & 0.443 & 12.740 & 3.562 & 0.17 & 2.056 & 0.15 \\
\hline R\&D exp. as a share of total sales (ratio) & 29.917 & 46.136 & 36.639 & 0.00 & 0.621 & 0.43 \\
\hline Exports as a share of total sales (ratio) & -0.549 & 17.348 & 2.141 & 0.34 & 1.936 & 0.16 \\
\hline Headquarters abroad (d) & -0.520 & 7.528 & 0.450 & 0.80 & 0.450 & 0.50 \\
\hline Constant & 1.849 & -33.007 & 16.171 & 0.00 & 13.955 & 0.00 \\
\hline $\mathrm{R}^{2}$ & 0.159 & 0.051 & & & & \\
\hline No. of obs. & 589 & 560 & & & & \\
\hline
\end{tabular}

$9 \quad \mathrm{AIC} 3=$ LogLikelihood -3 degrees of freedom 
We conduct Wald tests on whether a variable has a significant impact on the model as a whole (column "Wald") and whether these effects differ significantly between classes (column "Wald (=)"). Generally, we find that these results support the focus variable results from the initial tobit estimations. Public procurement and knowledge spillovers from universities have a significant impact on innovation success (sales with new-to-market products). The effect of university inputs is consistently positive across both classes. However, the effects of public procurement differ significantly between them. The effect is slightly negative for the base class and very positive for the focus class. Hence, we conclude that public procurement is not generally beneficial to all firms but most effective when directed at smaller firms in economically challenged regional markets (Eastern Germany) in both distributive and technological services.

One issue in the econometric analysis could be that firms do not participate or are not affected randomly by the specific policy instruments. As a consequence the results might be biased due to differences between participants and non-participants in important characteristics. In order to check the robustness of the effects we control for a potential selection by applying a nonparametric matching procedure (cf. Heckman et al. 1999). We conduct two matching estimations for the significant policy variables from the previous tobit estimation models: public procurement and university knowledge spillovers. The main results are confirmed by this approach (see appendix B for a short description of the approach and the corresponding results).

\section{Conclusions}

We conduct this study to analyze the effects of public technology procurement, a recently revitalized innovation policy tool, on firms' innovation success. We judge the effects of this instrument against other forms of public support, namely regulation, provision of infrastructure via universities and research institutions, and public R\&D subsidies. Our goal is to support policy makers with empirical evidence on two major research questions: Is public procurement an effective instrument to provide public support for innovation compared to other options and if so, for which firms does it work?

In a first step we compare the effects of the instruments on innovation success, measured as the share of turnover with market novelties. Then we investigate whether the effects of these forms are specific to certain structural features of firms. We find that public policy leverage points are neither limited to the supply nor the demand side. Public procurement has significant positive effects on innovation success but so does the provision of a knowledge infrastructure in universities spilling over to firms. Both effects have similar impacts on innovation success. Interestingly, the positive effects from public procurement stem from general administrative procurement and not from the needs of the military, police or fire departments.

However, the effects of each policy instrument may depend upon firm characteristics. In the second step of the analysis we question whether firms are fully homogenous in their response 
to certain forms of public support. Applying latent class tobit models we identify two subgroups of firms which are homogeneous in terms of their structural characteristics such as size, location (Eastern Germany) and industry. We discover that firms benefit equally from university knowledge across these firm subgroups. Thus, a policy of trying to generate knowledge spillovers from universities to firms could target all sectors and types of firms. In order to strengthen linkages between firms and universities and research institutions either firms can be encouraged to use universities' knowledge or universities can be given incentives to diffuse their knowledge and technologies more intensively (technology transfer).

We find that public procurement has heterogeneous effects on firm's innovation performance. It is effective in particular for smaller firms in regional areas under economic stress and in distributive and technological services. We suspect that public procurement may be especially promising for firms with limited resources. The fact that orders are typically large and come from reliable public entities provides these firms with the necessary planning reliability to engage in innovation activities which may otherwise be to expensive or risky. Besides, public procurement provides them with immediate sales opportunities, as opposed to support for research, which requires additional investments for exploitation in the future. Our results offer empirical evidence to support Geroski's suggestion "of supporting a wide range of small- and medium-size contractors capable of handling smaller projects" (Geroski, 1990: 196). Obviously, there are limits on how public procurement tenders can be tailored to specific firm characteristics. Then again, our results indicate that they have the greatest immediate impact on innovation outputs if small firms - especially in economically challenged regions - are aware of them and can participate in a way that suits their limited resources. This seems to be especially relevant when it comes to the public procurement of distributive and technological services.

We benefit from an extensive dataset of German firms and coverage of several important innovation policy instruments. However, the limitations of this study may provide fruitful paths for further research. One constraint of our analysis is that we cannot assess the efficiency of the different instruments, since we do not have information regarding the quantitative input provided by the government. We can only examine whether the interventions are adequate in general to accomplish a certain objective, namely the contribution to firms' innovation success. Furthermore, the study is static in nature. It would be helpful to have panel data in order to reveal effects of the interventions over longer periods of time. In addition, our results are limited to the German context. Comparative studies with other countries could provide valuable new insights. 


\section{References}

Aerts K., D. Czarnitzki and A. Fier (2007), Evaluación econométrica de la política pública de I+D: estado del arte, in: Heijs J. and M. Buesa: Cooperación en innovación en España: El papel del Estado, Instituto de Estudios Fiscales Madrid (Spain), 79-104.

Almus, M. and D. Czarnitzki (2003), The Effects of Public R\&D Subsidies on Firms' Innovation Activities: The Case of Eastern Germany, Journal of Business and Economic Statistics 21 (2), 226-236.

Andrews, R.L. and I.S. Currim (2003), A Comparison of Segment Retention Criteria for Finite Mixture Logit Models, Journal of Marketing Research 40 (2), 235-243.

Aschhoff, B. and T. Schmidt (2006), Empirical Evidence on the Success of R\&D Cooperation - Happy together?, ZEW Discussion Paper No. 06-059, Mannheim.

Belderbos, R., M. Carree and B. Lokshin (2004), Cooperative R\&D and Firm Performance, Research Policy 33, 1477-1492.

Bertrand, M. and S. Mullainathan (2001), Do People Mean What They Say? Implications for Subjective Survey Data, American Economic Review 91 (2), 67-72.

Blind, K. (2004), Can regulation be good for innovation?, Euroabstracts 42 (2), 8-9.

BMBF (2006), Hightech-Strategie für Deutschland, Bonn/Berlin.

BMBF (2007), Pressemitteilung 20. September 2007, 186/2007, Berlin.

Cohen, W.M., R.R. Nelson and J.P. Walsh (2002), Links and Impacts: The Influence of Public Research on Industrial R\&D, Management Science 48 (1), 1-23.

Cohen, L.R. and R.G. Noll (1991), The Technological Pork Barrel, The Brookings Institution, Washington, DC.

Colaghirou, Y, A. Tsakanikas and N.S. Vonortas (2001), University-Industry Cooperation in the Context of the European Framework Programmes, Journal of Technology Transfer 26, $153-161$.

Criscuolo, C., J.E. Haskel and M.J. Slaughter (2005), Global Engagement and the Innovation Activities of Firms, NBER Working Paper No. 11479, Cambridge, MA.

Czarnitzki, D. and A. Fier (2002), Do Innovation Subsidies Crowd out Private Investment? Evidence from the German Service Sector, Konjunkturpolitik - Applied Economics Quarterly $48(1), 1-25$.

Czarnitzki, D. and K. Hussinger (2004), The link between $R \& D$ subsidies, $R \& D$ input and technological performance, ZEW Discussion Paper 04-56, Mannheim. 
Czarnitzki, D. and G. Licht (2006), Additionality of Public R\&D Grants in a Transition Economy: The Case of Eastern Germany, Economics of Transition 14 (1), 101-131.

Dalpé, R. (1994), Effects of Government Procurement on Industrial Innovation, Technology in Society 16 (1), 65-83.

David, P.A., B.H. Hall and A.A. Toole (2000), Is public R\&D a complement or substitute for private R\&D? A review of the econometric evidence, Research Policy 29 (4-5), 497-529.

Duguet E. (2004), Are R\&D subsidies a substitute or a complement to privately funded R\&D? Evidence from France using propensity score methods for non experimental data, Revue d'Economie Politique 114 (2), 263-292.

Edler, J., S. Ruhland, S. Hafner, J. Rigby, L. Georghiou, L. Hommen, M. Rolfstam, C. Edquist, L. Tsipouri and M. Papadakou (2005), Innovation and Public Procurement. Review of Issues at Stake: Study for the European Commission (No ENTR/03/24), Final Report, Fraunhofer ISI, Karlsruhe

Edler, J. and L. Georghiou (2007), Public procurement and innovation - Resurrecting the demand side, Research Policy 36, 949-963.

Edquist, C. and L. Hommen (2000), Public Technology Procurement and Innovation Theory, in: C. Edquist, L. Hommen and L. Tsipouri (eds.), Public Technology Procurement and Innovation, Economics of Science, Technology, and Innovation 16, 5-70.

Edquist, C., L. Hommen and L. Tsipouri (2000), Introduction, in: C. Edquist, L. Hommen and L. Tsipouri (eds.), Public Technology Procurement and Innovation, Economics of Science, Technology, and Innovation 16, 1-4.

European Commission (2003), Investing in Research: An Action Plan for Europe, Communication COM(2003) 266 final/2, Brussels.

European Commission (2004), Innobarometer 2004, Flash Eurobarometer 164, Brussels.

European Commission (2006), Creating an Innovative Europe - Report of the Independent Expert Group on $R \& D$ and innovation appointed following the Hampton Court Summit and chaired by Mr. Esko Aho, EUR 22005, Luxembourg.

Fier, A. (2002), Staatliche Förderung industrieller Forschung in Deutschland, ZEW Wirtschaftsanalysen 62, Baden-Baden.

Fontana, R., A. Geuna and M. Matt (2006), Factors Affecting University-Industry R\&D Projects: The Importance of Searching, Screening and Signalling, Research Policy 35 (2), 309-323.

Fraunhofer Institute for Systems and Innovation Research (2004), New Products and Services: Analysis of Regulations Shaping New Markets - Final Report for European Commission, Luxembourg. 
Georghiou, L., E. Amanatidou, H. Belitz, L. Cruz, J. Edler, C. Edquist, O. Granstrand, J. Guinet, E. Leprince, L. Orsenigo, J. Rigby, J. Romanainen, M. Stampfer and J. van en Biesen (2003), Raising EU R\&D Intensity: Improving the Effectiveness of Public Support Mechanisms for Private Sector Research and Development: Direct Measures, EUR 20716.

Geroski, P.A. (1990), Procurement policy as a tool of industrial policy, International Review of Applied Economics 4 (2), 182-198.

Grimpe, C. and W. Sofka (2008), Search Patterns and Absorptive Capacity: Low- and HighTechnology Sectors in European Countries, Research Policy, forthcoming.

Hagenaars, J.A. and A.L. McCutcheon (2002), Applied Latent Class Analysis, Cambridge.

Heckman, J.J., H. Ichimura and P.E. Todd (1997), Matching as an Econometric Evaluation Estimator: Evidence from Evaluating a Job Training Programme, Review of Economic Studies 64, 605-654.

Heckman, J.J., R.J. Lalonde and J.A. Smith (1999), The economics and econometrics of active labor market programs, in: Ashenfelter, A. and D. Card (eds.), Handbook of labor economics 3, Amsterdam, 1866-2097.

Jaffe, A.B., S.R. Peterson and P.R. Portney (1995), Environmental Regulation and the Competitiveness of U.S. Manufacturing: What the Evidence Tell us?, Journal of Economic Literature XXXIII, 132-163.

James, A.D. (2004), U.S. Defence R\&D Spending: An Analysis of the Impacts Rapporteur's report for the EURAB Working Group ERA Scope and Vision, EURAB 04.11, Manchester.

Jensen, M.B., B. Johnson, E. Lorenz and B.A. Lundvall (2007), Forms of Knowledge and Modes of Innovation, Research Policy 36 (5), 680-693.

Kaiser, U. (2002), An Empirical Test of Models Explaining Research Expenditures and Research Cooperation: Evidence for the German Service Sector, International Journal of Industrial Organization 20 (6), 747-774.

Laursen, K. and A. Salter (2006), Open for Innovation: The Role of Openness in Explaining Innovation Performance among U.K. Manufacturing Firms, Strategic Management Journal 27 (2), 131-150.

Lazarsfeld, P.F. (1950), The Logical and Mathematical Foundations of Latent Structure Analysis, in: Stouffer, S. A. (ed.) Measurement and Prediction, Volume IV of the American Soldier: Studies in Social Psychology in World War II, Princeton, 362-412.

Lichtenberg, F.R. (1989), The Impact of the Strategic Defense Initiative on US Civilian R\&D Investment and Industrial Competitiveness, Social Studies of Science 19 (2), 265-282. 
Lööf, H. and A. Broström (2008), Does Knowledge Diffusion between University and Industry Increase Innovativeness?, Journal of Technology Transfer 33, 73-90.

Mansfield, E. (1991), Academic research and industrial innovation, Research Policy 20, 112.

Miotti, L. and F. Sachwald (2003), Co-operative R\&D: why and with whom? An integrated framework of analysis, Research Policy 32, 1481-1499.

Nelson, R.R. and N. Rosenberg (1993), Technical Innovation and National Systems, in: R.R. Nelson (ed.): National Innovation Systems: A Comparative Analysis, New York, 3-21.

Neter, J., W. Wasserman and M.H. Kutner (1990), Applied Linear Statistical Models: Regression, Analysis of Variance, and Experimental Designs, 3th ed., Homewood/Bosten.

OECD (1997), The OECD Report on Regulatory Reform: Synthesis, Paris.

OECD (2005), Oslo Manual: Guidelines for Collecting and Interpreting Innovation Data, Paris.

Palmberg, C. (2004), The sources of innovations - looking beyond technological opportunities, Economics of Innovation and New Technology 13 (2), 183-197.

Perkmann, M. and K. Walsh (2007), University-industry relationships and open innovation: Towards a research agenda, International Journal of Management Review 9 (4), 259-280.

Pavitt, K. (1991), What makes basic research economically useful?, Research Policy 20, 109-119.

Porter, M.E. (1991), America's green strategy, Scientific American 264 (4), 168.

Rabe-Hesketh, S. and B.S. Everitt (2007), A Handbook of Statistical Analyses Using Stata, 4th ed., Boca Raton, FL.

Rammer, C., B. Peters, T. Schmidt, B. Aschhoff, T. Doherr and H. Niggemann (2005), Innovationen in Deutschland - Ergebnisse der Innovationserhebung 2003 in der deutschen Wirtschaft, ZEW Wirtschaftsanalysen 78, Baden-Baden.

Rothwell, R. and W. Zegveld (1981), Industrial Innovation and Public Policy: Preparing for the 1980s and the 1990s, London.

Rothwell, R. (1984), Technology based small firms and regional innovation potential: the role of public procurement, Journal of Public Policy 4 (4), 307-332.

Schartinger, D., C. Rammer, M.M. Fischer and J. Fröhlich (2002), Knowledge interactions between universities and industry in Austria: sectoral patterns and determinants, Research Policy 31 (3), 303-328. 
Sianesi, B. (2004), An Evaluation of the Swedish System of Active Labor Market Programs in the 1990s, The Review of Economics and Statistics 86 (1), 133-155.

Stoneman, P. (1987), The economics analysis of technology policy, Oxford.

TAB (2006), Summary of TAB working report No.99 - Demand-oriented Innovation Policy.

Tidd, J., J. Bessant and K. Pavitt (1997), Managing Innovation: Integrating Technological, Market and Organisational Change, Chichester.

Vermunt, J.K. and J. Magidson (2005), Technical Guide for Latent Gold 4.0: Basic and Advanced, Belmont, Massachusetts.

Viscusi, W.K. and M.J. Moore (1993), Product Liability, Research and Development, and Innovation, The Journal of Political Economy 101 (1), 161-184.

Von Hippel, E. (1986), Lead Users: A source of Novel Product Concepts, Management Science 32 (7), 791-805. 


\section{Appendix A}

Table 6: Industry classification

\begin{tabular}{lll}
\hline Industry & NACE Code & Industry Group \\
\hline Mining and quarrying & $10-14$ & Other manufacturing \\
Food and tobacco & $15-16$ & Other manufacturing \\
Textiles and leather & $17-19$ & Other manufacturing \\
Wood / paper / publishing & $20-22$ & Other manufacturing \\
Chemicals / petroleum & $23-24$ & Medium high-tech manufacturing \\
Plastic / rubber & 25 & Other manufacturing \\
Glass / ceramics & 26 & Other manufacturing \\
Metal & $27-28$ & Other manufacturing \\
Manufacture of machinery and equipment & 29 & Medium high-tech manufacturing \\
Manufacture of electrical machinery & $30-32$ & High-tech manufacturing \\
Medical, precision and optical instruments & 33 & High-tech manufacturing \\
Manufacture of motor vehicles & $34-35$ & Medium high-tech manufacturing \\
Manufacture of furniture, jewellery, sports & $36-37$ & Other manufacturing \\
equipment and toys & & \\
Electricity, gas and water supply & $40-41$ & Other manufacturing \\
Construction & 45 & Other manufacturing \\
Retail and motor trade & 50,52 & Distributive services \\
Wholesale trade & 51 & Distributive services \\
Transportation and communication & $60-63,64.1$ & Distributive services \\
Financial intermediation & $65-67$ & Knowledge-intensive services \\
Real estate and renting & $70-71$ & Distributive services \\
ICT services & $72,64.2$ & Technological services \\
Technical services & $73,74.2,74.3$ & Technological services \\
Consulting & $74.1,74.4$ & Knowledge-intensive services \\
Other business-oriented services & $74.5-74.8,90$ & Distributive services \\
\hline
\end{tabular}

Table 7: Variance inflation factors

\begin{tabular}{lc}
\hline Variable & VIF \\
\hline Focus Variables & 1.07 \\
Innovation Source: Public procurement (d) & 1.11 \\
Innovation Source: Regulation (d) & 1.17 \\
Innovation Source: Domestic university (d) & 1.28 \\
Public R\&D subsidy (d) & 1.19 \\
Control Variables & 1.35 \\
Continuous R\&D (d) & 1.43 \\
R\&D expenditure as a share of total sales (ratio) & 1.23 \\
No. of employees (logs) & 1.23 \\
Firm age (years) & 1.42 \\
Location Eastern Germany (d) & 1.07 \\
Exports as a share of total sales (ratio) & 1.45 \\
Headquarters abroad (d) & 1.33 \\
Medium-high technology manufacturing (d) & 1.18 \\
High technology manufacturing (d) & 1.23 \\
Distributive services (d) & 1.63 \\
Knowledge-intensive services (d) & 1.27 \\
Technological services (d) & \\
\hline Mean & \\
\hline
\end{tabular}




\section{Table 8: Correlation table (1,149 observations)}

\begin{tabular}{|c|c|c|c|c|c|c|c|c|c|c|c|c|c|c|c|c|}
\hline & (1) & $(2)$ & (3) & (4) & $(5)$ & $(6)$ & (7) & $(8)$ & (9) & $(10)$ & $(11)$ & (12) & $(13)$ & (14) & $(15)$ & $(16)$ \\
\hline Innovation Source: Public procurement (1) & 1.00 & & & & & & & & & & & & & & & \\
\hline Innovation Source: Regulation (2) & 0.16 & 1.00 & & & & & & & & & & & & & & \\
\hline Innovation Source: Domestic university (3) & 0.14 & 0.19 & 1.00 & & & & & & & & & & & & & \\
\hline Public R\&D subsidy (4) & 0.07 & 0.10 & 0.27 & 1.00 & & & & & & & & & & & & \\
\hline Cont. R\&D activities (5) & 0.04 & 0.04 & 0.14 & 0.23 & 1.00 & & & & & & & & & & & \\
\hline Public R\&D funding (6) & 0.01 & 0.08 & 0.21 & 0.31 & 0.21 & 1.00 & & & & & & & & & & \\
\hline No of employees (7) & 0.01 & 0.03 & 0.04 & 0.09 & 0.08 & 0.27 & 1.00 & & & & & & & & & \\
\hline Company age (8) & 0.04 & 0.07 & 0.05 & 0.11 & 0.02 & 0.15 & 0.34 & 1.00 & & & & & & & & \\
\hline Location in East Germany (9) & 0.04 & 0.02 & 0.02 & 0.22 & 0.01 & 0.17 & 0.25 & 0.30 & 1.00 & & & & & & & \\
\hline Export share of sales (10) & 0.09 & 0.06 & 0.00 & 0.03 & 0.21 & 0.01 & 0.32 & 0.18 & 0.20 & 1.00 & & & & & & \\
\hline Headquarters abroad (11) & 0.02 & 0.10 & 0.00 & 0.00 & 0.01 & 0.05 & 0.20 & 0.06 & 0.05 & 0.17 & 1.00 & & & & & \\
\hline Medium-high technology manufacturing (12) & 0.05 & 0.02 & 0.01 & 0.06 & 0.16 & 0.04 & 0.16 & 0.09 & 0.05 & 0.32 & 0.09 & 1.00 & & & & \\
\hline High technology manufacturing (13) & 0.02 & 0.03 & 0.04 & 0.08 & 0.07 & 0.14 & 0.00 & 0.01 & 0.04 & 0.10 & 0.04 & -0.23 & 1.00 & & & \\
\hline Distributive services (14) & 0.02 & 0.02 & 0.09 & 0.08 & 0.20 & 0.10 & 0.01 & 0.01 & 0.00 & -0.15 & -0.02 & -0.15 & -0.11 & 1.00 & & \\
\hline Knowledge-intensive services (15) & 0.03 & 0.10 & 0.01 & 0.08 & 0.10 & 0.04 & 0.08 & 0.01 & 0.05 & -0.22 & 0.00 & -0.16 & -0.11 & -0.07 & 1.00 & \\
\hline Technological services (16) & 0.11 & 0.10 & 0.19 & 0.18 & 0.03 & 0.30 & 0.31 & 0.19 & 0.05 & -0.22 & -0.09 & -0.25 & -0.17 & -0.12 & -0.12 & 1.00 \\
\hline
\end{tabular}




\section{Appendix B}

The matching approach is commonly used in the analysis of public R\&D subsidies where a selection problem arises (see, e.g., Czarnitzki and Fier, 2002 or Duguet, 2004). In order to check the robustness of the found effects we control for a potential selection by applying the matching procedure. We conduct two matching estimations for the significant policy variables from the previous tobit estimation models: public procurement and university knowledge spillovers. The respective policy instrument is called treatment. The outcome variable in our setting is the share of turnover with market novelties. The basic idea of the matching approach is to balance the sample of participants with comparable non-participants individually for each observation with respect to the variables included in the matching procedure. The remaining differences in the outcome variable between both groups are then attributed to the treatment (Heckman et al. 1997).

In order to identify the average treatment effect (ATT) two assumptions have to hold: the Conditional Independence Assumption (CIA) and common support. The CIA implies that all the characteristics which influence both treatment and outcome have to be observed. Common support requires that for each treated observation a similar control can be found. Given the broad range of variables in our dataset we are confident that we have enough information on the firms to sufficiently approximate the treatment and the outcome so that the CIA holds. To ensure that common support for the treated firms is fulfilled in the matching procedure, only one treated observation has to be dropped.

Before proceeding to the actual matching, two probit models were estimated on the probabilities of having public procurement and universities as important information sources (for a detailed description of the matching procedure see, e.g., Czarnitzki and Fier, 2002). The results of the two probit estimations can be found in Table 9. The propensity score of this estimation is labeled PSCORE. In order to find a control observation for each treated firm, the nearest neighbor approach with replacement, based on the Mahalanobis distance is applied. Besides PSCORE the Mahalanobis metric restriction is defined by the other three policy interventions - to ensure that treated and control firms are affected by the same policy interventions -, industry group dummies, and the location (Eastern Germany).

Table 10 illustrates the differences for the considered characteristics and the outcome variables after the two matching procedures between the treated and control groups: firms with public procurement and universities as important sources, as the treatment group, respectively, and firms without the intervention as the control group. The matching estimator is successful in balancing out the differences for the considered variables between the treated and the control group as shown by the t-Tests. Hence, it is possible to estimate the causal effect of the treatment on the firms. In order to evaluate the quality of the matching we reestimate the propensity score by using only the matched sample and taking account of replacement in the control group by weighting. As stated by Sianesi (2004) the pseudo-R2 after matching should be quite low because there should be no more systematic differences in the regressors between treated and control companies. In our setting, the Pseudo-R2 after the 
re-estimation is fairly low. Furthermore, a likelihood ratio suggests that there is no joint significance of all covariates of the probit model after matching in both estimations.

Comparing the outcome variable for the two groups it can be seen that the variable is significantly larger for the treated groups - firms with public procurement and universities, compared to the respective control groups. We find that both public procurement and university spillovers have a significantly positive influence on the success with innovation. Thus, the main results are confirmed by this approach.

\section{Table 9: Probit estimation results}

\begin{tabular}{|c|c|c|}
\hline & $\begin{array}{l}\text { Innovation Source: } \\
\text { Public procurement }\end{array}$ & $\begin{array}{l}\text { Innovation Source: } \\
\text { Domestic university }\end{array}$ \\
\hline Innovation Source: Public procurement (d) & & $\begin{array}{c}0.51 * * * \\
(0.19)\end{array}$ \\
\hline Innovation Source: Regulation (d) & $\begin{array}{c}0.57 * * * \\
(0.15)\end{array}$ & $\begin{array}{c}0.51 * * * \\
(0.12)\end{array}$ \\
\hline Innovation Source: Domestic university (d) & $\begin{array}{l}0.42 * * \\
(0.18)\end{array}$ & \\
\hline Public R\&D subsidy (d) & $\begin{array}{c}0.18 \\
(0.16)\end{array}$ & $\begin{array}{c}0.70 * * * \\
(0.11)\end{array}$ \\
\hline Continuous R\&D (d) & $\begin{array}{c}0.29 \\
(0.20)\end{array}$ & $\begin{array}{c}0.42 * * \\
(0.20)\end{array}$ \\
\hline R\&D expenditure as a share of total sales (ratio) & $\begin{array}{c}-1.86 * * \\
(0.81)\end{array}$ & $\begin{array}{l}0.90 * * \\
(0.44)\end{array}$ \\
\hline No. of employees (logs) & $\begin{array}{c}0.03 \\
(0.04)\end{array}$ & $\begin{array}{c}0.02 \\
(0.03)\end{array}$ \\
\hline Firm age (years) & $\begin{array}{l}-0.00 \\
(0.01)\end{array}$ & $\begin{array}{l}-0.00 \\
(0.00)\end{array}$ \\
\hline Location Eastern Germany (d) & $\begin{array}{c}0.20 \\
(0.17)\end{array}$ & $\begin{array}{l}-0.14 \\
(0.12)\end{array}$ \\
\hline Exports as a share of total sales (ratio) & $\begin{array}{l}-0.62 \\
(0.39)\end{array}$ & $\begin{array}{c}0.04 \\
(0.23)\end{array}$ \\
\hline Headquarters abroad (d) & $\begin{array}{l}0.16 \\
(0.22)\end{array}$ & $\begin{array}{c}0.03 \\
(0.19)\end{array}$ \\
\hline Medium-high technology manuf. (d) & $\begin{array}{c}0.08 \\
(0.23)\end{array}$ & $\begin{array}{c}0.13 \\
(0.15)\end{array}$ \\
\hline High technology manuf. (d) & $\begin{array}{l}0.47 * * \\
(0.23)\end{array}$ & $\begin{array}{c}0.26 \\
(0.17)\end{array}$ \\
\hline Distributive services $(\mathrm{d})$ & $\begin{array}{l}0.51 * \\
(0.27)\end{array}$ & $\begin{array}{l}-0.74 \\
(0.46)\end{array}$ \\
\hline Knowledge-intensive services (d) & $\begin{array}{l}0.46^{*} \\
(0.27)\end{array}$ & $\begin{array}{l}0.40 * \\
(0.23)\end{array}$ \\
\hline Technological services $(d)$ & $\begin{array}{c}0.67 * * * \\
(0.22)\end{array}$ & $\begin{array}{c}0.55 * * * \\
(0.17)\end{array}$ \\
\hline Constant & $\begin{array}{c}-2.51 * * * \\
(0.31)\end{array}$ & $\begin{array}{c}-2.31 * * * \\
(0.30)\end{array}$ \\
\hline Wald $\chi^{2}$ & 81.86 & 128.49 \\
\hline P-value & 0.00 & 0.00 \\
\hline Pseudo $\mathrm{R}^{2}$ & 0.14 & 0.19 \\
\hline No. of obs. & 1,149 & 1,149 \\
\hline $\begin{aligned} \text { Notes: } & * * *(* *, *) \text { indicate a significance level } \\
& \text { the joint significance of the explanatory } \\
& \text { Coefficients are shown (standard errors }\end{aligned}$ & $\begin{array}{l}0 \% \text { ). Wald } \chi^{2} \text { displays } \\
\text { e next line reports the }\end{array}$ & $\begin{array}{l}\text { ld test statistic for } \\
\text { onding p-value. }\end{array}$ \\
\hline
\end{tabular}


Table 10: Results after matching

\begin{tabular}{|c|c|c|c|c|c|c|}
\hline \multirow[t]{3}{*}{ Treatment } & \multicolumn{3}{|c|}{$\begin{array}{l}\text { Innovation Source: } \\
\text { Public procurement }\end{array}$} & \multicolumn{3}{|c|}{$\begin{array}{l}\text { Innovation Source: } \\
\text { Domestic university }\end{array}$} \\
\hline & \multicolumn{2}{|c|}{ Mean } & \multirow{2}{*}{$\begin{array}{l}\text { p-value } \\
\text { of t-test }\end{array}$} & \multicolumn{2}{|c|}{ Mean } & \multirow{2}{*}{$\begin{array}{l}\text { p-value } \\
\text { of t-test }\end{array}$} \\
\hline & Treated & Control & & Treated & Control & \\
\hline PSCORE & 0.113 & 0.106 & 0.716 & 0.265 & 0.263 & 0.943 \\
\hline Inno. Source: Public procurement (d) & 1 & 0 & & 0.124 & 0.124 & 1.000 \\
\hline Inno. Source: Regulation (d) & 0.444 & 0.444 & 1.000 & 0.372 & 0.372 & 1.000 \\
\hline Inno. Source: Domestic university (d) & 0.315 & 0.315 & 1.000 & 1 & 0 & \\
\hline Public R\&D subsidy (d) & 0.481 & 0.481 & 1.000 & 0.690 & 0.690 & 1.000 \\
\hline Continuous R\&D (d) & 0.870 & 0.796 & 0.306 & 0.952 & 0.952 & 1.000 \\
\hline R\&D exp. as a share of total sales (ratio) & 0.057 & 0.050 & 0.741 & 0.125 & 0.118 & 0.724 \\
\hline No. of employees $(\operatorname{logs})$ & 4.427 & 4.166 & 0.527 & 4.326 & 3.997 & 0.152 \\
\hline Firm age (years) & 14.778 & 12.926 & 0.533 & 15.297 & 14.407 & 0.632 \\
\hline Location Eastern Germany (d) & 0.407 & 0.444 & 0.700 & 0.359 & 0.393 & 0.546 \\
\hline Exports as a share of total sales (ratio) & 0.134 & 0.144 & 0.815 & 0.235 & 0.263 & 0.404 \\
\hline Headquarters abroad (d) & 0.111 & 0.037 & 0.144 & 0.090 & 0.069 & 0.516 \\
\hline Medium-high technology manuf. (d) & 0.148 & 0.222 & 0.326 & 0.241 & 0.262 & 0.686 \\
\hline High technology manuf. (d) & 0.167 & 0.148 & 0.794 & 0.172 & 0.172 & 1.000 \\
\hline Distributive services (d) & 0.093 & 0.037 & 0.245 & 0.007 & 0.007 & 1.000 \\
\hline Knowledge-intensive services (d) & 0.111 & 0.167 & 0.409 & 0.076 & 0.041 & 0.213 \\
\hline Technological services $(d)$ & 0.333 & 0.315 & 0.839 & 0.345 & 0.386 & 0.466 \\
\hline Share of turnover with market novelties ${ }^{\text {a) }}$ & 15.559 & 7.111 & 0.030 & 14.272 & 10.103 & 0.089 \\
\hline No. of matched pairs & & 54 & & & 145 & \\
\hline
\end{tabular}

a) T-test is based on bootstrapped standard errors of the estimates; no. of replications: 100 . 